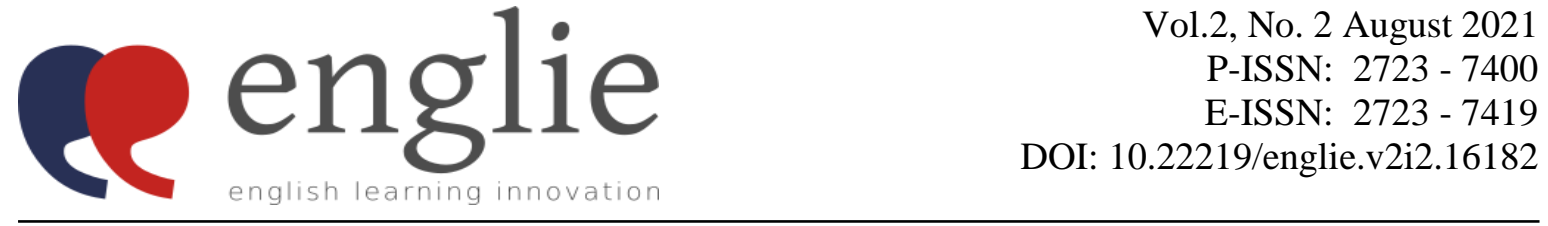

\section{Social Function of Maxim to Present "Coming of Age" Value through Bildungsroman Novel Translation Entitled Norwegian Wood by Haruki Murakami}

\author{
Gandis Octya Prihartanti \\ Translation Studies, Postgraduate Program of Linguistics, Sebelas Maret University, Indonesia
}

Corresponding Author: gandis.octya@gmail.com

\begin{abstract}
This study aims to identify maxim utterance in Bildungsroman novel entitled Norwegian Wood by Haruki Murakami as well as translation technique used. Another purpose is to know the value of "coming of age." This is a qualitative study which means the data were collected through document review from two sources including research object and rater assessment. The result shows that there are nine translation techniques applied, they are: established equivalent (amplification), explicitation and paraphrase, reduction, variation, creation discursive, modulation, paraphrase, pure borrowing, generalization, linguistic compression (implicitation). Regarding to quality of accuracy, acceptability, and readability, the following findings are shown as follows: accurate: $80 \%$, less accurate $10 \%$, not accurate $10 \%$, acceptable $100 \%$, less acceptable $0 \%$, not acceptable $0 \%$, readable $100 \%$, less readable $0 \%$, and not readable $0 \%$.
\end{abstract}

Keywords: bildungsroman, coming of age, maxim, translation, translation techniques

\section{INTRODUCTION}

An utterance is a common instrument of communication used in daily life. Practically, there are two participants who involved in that event namely speaker and hearer. The indicator of successful communication is when the hearer can infer the speaker's meaning from the utterance. In addition, it is not only about recognize linguistic meaning, but also involves context as the main foothold in capturing the meaning of utterance. It can be said that a form of utterance has different intention because a speaker wants to convey something indirectly.

Permatasari and Yulia (2016) found that the utterances in advertising have three functions, namely legitimate power, reward power, and referent power. Meanwhile, another study conducted by Dänzer (2017) found that utterance is to show someone's knowledge and 
beliefs. In line with this, the utterance has its own function as conveyed in the research of Sua, Anshari, and Maman (2017) entitled "The Form, Function, and Value of Buginese Utterances of Bone Society." In short, the utterance has a flexible function relates to event, purpose, and its target.

Exhaustively, there is a conversational principle which is called as maxim. Cutting (2002) defines four categories of maxim as follows: maxim of quality means to speak your utterance is true or can be said do not say what you believe to be false and do not say that for which you lack adequate evidence. Maxim of quantity means your contribution of speak as informative as is required (for the current purposes of the exchange) and do not make your contribution more informative than is required. Maxim of relevance means be relative as a response to the speaker's utterance. Last, maxim of manner means be perspicuous by avoid obscurity of expression, avoid ambiguity, be brief (avoid unnecessary prolixity), and be orderly. To create a story, a writer can present communication between characters through dialogue. It is also useful to show attitude and value which is presented by them. Moreover, to obtain specific value, a reader can choose a genre which loads its substance. For instance, Bildungsroman as a genre in which focuses on the psychological and moral growth of the protagonist from youth to adulthood, so character change is the salient thing.

Bildungsroman is a type of novel which is a "novel of formation" or a "novel of education." It focuses on the development of the mind and character of the young protagonist from childhood to adulthood. The genre is first introduced by Karl Mongstern in the nineteenth century and was popularized by Wilhelm Dilthey in the twentieth century. It is a German term, Bildung means “formation" and Roman means “novel." Goethe's Wilhelm Meister (1976) was first categorized under this genre. The genre focuses on the all-round development of the protagonist (Christy, 2016). On the other hand, Bildungsroman refers to "coming of age" in which the protagonist searches for answering life's question through many experience including sensitive things. Moreover, that experience is kind of maturity journey of protagonist.

According to a website named Whiteboard Journal, Indonesian literature is still lacking in coming of age stories. Last published books were around the 2000s. This is caused by two extreme dichotomous poles which do not allow the coming of age story to be placed in either one or in between. On the one hand, there is a "serious" literary work which breaks through the discussion of sexuality full of symbolism to satirical criticism of certain socio-political conditions. In contract, at the other pole, the literary work "popular" frames inspiring stories 
that are inspirational in the theme of pseudo religiosity and shallow nationalism but still selling well in the market.

Therefore, on the market, a story with Bildungsroman genre tends to be filled with translation products. However, based on the reasons above regarding the existence of Bildungsroman genre stories which are rarely available in Indonesian literature, a filtering tool is needed to be accepted by the people of this country who uphold morality and politeness. The filter tool is the process of translating the Bildungsroman genre story itself. Translators must be able to divert messages in a special way that is looking for a subtler equivalent without reducing the substance of the story as a message for the reader.

\section{METHOD}

This research is a qualitative descriptive study with a case study design that is embedded and oriented towards translation products. That is because before the research was done, the focus of the research was in the form of the main variables studied which were determined in advance based on the objectives and research interests (Sutopo in Yulinda, 2018). Data source, research location, and informants were selected based on certain criteria (purposive sampling techniques). They are a translation of utterance was observed maxim in the Bildungsroman genre novel entitled Norwegian Wood by Haruki Murakami. The data is ultimately used to see the value of "coming of age" of the story that is presented. This research is a qualitative descriptive study, because the research was conducted through document review (Moleong, 2005). This research is descriptive due to the data in the form of sentences in the utterance, so that it can trigger the emergence of a more tangible understanding than just a number or frequency presentation (Sutopo, 2006).

In this study, researcher identified the type of maxim found in dialogue on a novel titled Norwegian Wood by Haruki Murakami. Then, the researcher analyzed the translation techniques used. Finally, the data source was used to see the "coming of age" message contained in the story. The data in this study were divided into two namely linguistic data and translation data. Linguistic data was the utterance which observe the maxim in dialogue on the novel titled Norwegian Wood by Haruki Murakami. Then, for the translation data includes the translation techniques was used to translate the utterance as well as the quality level aspects which include accuracy, acceptance, and readability. Data collection was done by document analysis (content analysis) and focus group discussions (FGD) conducted with two raters. This 
technique was used to gain a clear picture of the use of the impact of translation techniques on the quality of the translation.

\section{FINDINGS AND DISCUSSION}

In regards to the utterance, the cooperative principle that was coined by Cutting can be used as a reference whether the utterance can connect the understanding between the speaker and the hearer. In the cooperative principle, the term maxim is known in which refers to the expressing statement made by the two participants.

In identifying maxim, there are four types of maxim, namely quality, quantity, relevance, and manner. The four categories are useful for knowing the speaker's intention, so the hearer can provide the appropriate response. In relation to utterance which observe the maxim with a dialogue that is presented in a story, the reader can find a message contained through the style of speech that has been classified. According to the purposive sampling technique, the data obtained can be presented in table as follows:

Table 1. Types of maxim, examples, and analyzes taken from research objects

\section{Quality}

\begin{tabular}{|c|c|c|c|}
\hline No & BSu & BSa & Analysis \\
\hline 1 & $\begin{array}{l}\text { A: “Are you } \\
\text { sure?" } \\
\text { B: "Yes, I'm } \\
\text { sure. Thanks." } \\
\text { (p.5) }\end{array}$ & $\begin{array}{l}\text { A: “Betul, tidakapa-apa?" } \\
\text { B: “Tidak apa-apa, terima } \\
\text { kasih,” kataku (p.1-2) }\end{array}$ & $\begin{array}{l}\text { A flight attendant asks a passenger } \\
\text { who does not look okay. The } \\
\text { passenger said he was fine, because } \\
\text { what made him look not fine was a } \\
\text { memory that was on his mind, not } \\
\text { caused by travel. }\end{array}$ \\
\hline 2 & $\begin{array}{l}\text { A: "Really?" } \\
\text { B: "Don't be } \\
\text { ridiculous, I'm } \\
\text { kidding," she } \\
\text { said, shaking her } \\
\text { head with a }\end{array}$ & $\begin{array}{l}\text { A: “Sungguh?” tanyaku. } \\
\text { B: "Bohong, dong. Nggak } \\
\text { mungkinlah," katanya } \\
\text { sambil menggeleng- } \\
\text { gelengkan kepala, seolah tak } \\
\text { percaya. (p. 144) }\end{array}$ & $\begin{array}{l}\text { Speaker B confirmed Speaker's A } \\
\text { response that her statement was just } \\
\text { a joke. Then, she revealed the truth } \\
\text { about her background as a therapist. }\end{array}$ \\
\hline
\end{tabular}


look of disgust.

(p.118)

3 A: "Didn't the

A: "Apa perempuan-

The reason given by Speaker B is

girls mind?"

perempuan itu tidak

very plausible, because when

B: "No, they

marah?"

someone is drunk his or her

were drunk too."

B: "Mereka mabuk, consciousness will be disturbed.

(p.246) jadisiapa pun bagi mereka

tak masalah.” (p.304)

\begin{tabular}{|c|c|c|c|}
\hline 4 & $\begin{array}{l}\text { A: "What do you } \\
\text { mean } \\
\text { really cute?" } \\
\text { B: "So cute the } \\
\text { mountains } \\
\text { crumble and the } \\
\text { oceans dry up." } \\
\text { (p. } 276)\end{array}$ & $\begin{array}{l}\text { A: "Seberapa manis?" } \\
\text { B: "Manis sekali, sampai } \\
\text { gunung bisa runtuh dan } \\
\text { sampai laut bisa kering." } \\
\text { (p.340) }\end{array}$ & $\begin{array}{l}\text { Although Speaker A intends to } \\
\text { seduce Speaker B with hyperbolic } \\
\text { expressions, Speaker B believes in } \\
\text { that. It was proven by her reaction } \\
\text { to praise the seduction. }\end{array}$ \\
\hline 5 & $\begin{array}{l}\text { A: "Tell me this } \\
\text { isn't a dream," } \\
\text { said Reiko, } \\
\text { sniffing the air. } \\
\text { B: "No, this is } \\
\mathbf{1 0 0} \text { per cent } \\
\text { realistic } \\
\text { sukiyaki," I said. } \\
\text { "Empirically } \\
\text { speaking, of } \\
\text { course." (p.343) }\end{array}$ & $\begin{array}{l}\text { A: "Ini bukan mimpi, kan? } \\
\text { Reiko-san sambil } \\
\text { mengendus-endus bau } \\
\text { masakan. } \\
\text { B: "Sukiyaki tulen seratus } \\
\text { persen. Kalau harus } \\
\text { kukatakan secara } \\
\text { empiris," kataku. (p.416) }\end{array}$ & $\begin{array}{l}\text { Speaker B guarantees his statement } \\
\text { is true from the experience he has } \\
\text { gained. }\end{array}$ \\
\hline
\end{tabular}




\section{Quantity}

\begin{tabular}{|c|c|c|c|}
\hline No & BSu & BSa & Analysis \\
\hline 6 & $\begin{array}{l}\text { A: "Tell me } \\
\text { something, Toru," } \\
\text { she said. "Do you } \\
\text { love me? } \\
\text { B: "You know I } \\
\text { do." (p.12) }\end{array}$ & $\begin{array}{l}\text { A: "Watanabe, kau } \\
\text { menyukaiku?" } \\
\text { B: “Tentu saja," jawabku. } \\
\text { (p.10) }\end{array}$ & $\begin{array}{l}\text { Speaker B directly answers } \\
\text { questions from Speaker A which } \\
\text { means providing information to } \\
\text { Speaker A directly without any } \\
\text { other utterances. }\end{array}$ \\
\hline 7 & $\begin{array}{l}\text { A: "I don't } \\
\text { suppose you're } \\
\text { going to come in } \\
\text { and rape us in the } \\
\text { middle of } \\
\text { the night?" } \\
\text { B: 'Don't be } \\
\text { silly." (p.120) }\end{array}$ & $\begin{array}{l}\text { A: “Anda tidak akan masuk } \\
\text { ke kamart idur kami, } \\
\text { berbuat macam-macam, lalu } \\
\text { memperkosa kami, kan?" } \\
\text { B: "Ya, tentutidak." } \\
\text { (p.147) }\end{array}$ & $\begin{array}{l}\text { Speaker B gave a short answer } \\
\text { without giving his defense as a } \\
\text { promise that he would not do } \\
\text { anything wrong. }\end{array}$ \\
\hline 8 & $\begin{array}{l}\text { A: "For } \\
\text { instance?" } \\
\text { B: "Hiking. } \\
\text { Swimming. } \\
\text { Reading." } \\
\text { (p.138) }\end{array}$ & $\begin{array}{l}\text { A: “Apa hobimu?" } \\
\text { B: “Bepergian dengan } \\
\text { jalan kaki, berenang, dan } \\
\text { membaca buku.” (p.169) }\end{array}$ & $\begin{array}{l}\text { Speaker A is a therapist who wants } \\
\text { to dig up information on Speaker B } \\
\text { as a client who has a dark life. He } \\
\text { only answers as necessary without } \\
\text { giving reasons why he likes these } \\
\text { activities. }\end{array}$ \\
\hline 9 & $\begin{array}{l}\text { A: "Was there } \\
\text { something you } \\
\text { wanted to talk } \\
\text { about?" } \\
\text { B: "Nothing } \\
\text { special. I } \\
\text { just called." } \\
\text { (p.201) }\end{array}$ & $\begin{array}{l}\text { A: “Ada keperluan apa?” } \\
\text { B: “Tak ada, Cuma } \\
\text { menelepon saja.” (p.249) }\end{array}$ & $\begin{array}{l}\text { Speaker B only answers briefly so } \\
\text { Speaker A creates a follow-up } \\
\text { conversation. }\end{array}$ \\
\hline
\end{tabular}


10 A: "So how did you lose so much weight?'

$\mathrm{B}$ : "By growing up," I said. (p.298)
A: "Kalau begitu kenapa

bisa sekurus itu?"

B: "Karena aku sudah

dewasa," kataku. (p.363)
Previously, Speaker A was

guessing why Speaker B could

experience a drastic weight loss.

However, when mentioned one brief reason, Speaker A can grasp a broader implied purpose.

\section{Relevance}

\begin{tabular}{|c|c|c|c|}
\hline No & BSu & BSa & Analysis \\
\hline 11 & $\begin{array}{l}\text { A: "Hey, can you } \\
\text { do that on the } \\
\text { roof or } \\
\text { somewhere?" I } \\
\text { said. "I can't } \\
\text { sleep." } \\
\text { B: "But it's } \\
\text { already 6.30!" } \\
\text { (p.21) }\end{array}$ & $\begin{array}{l}\text { A: “Tolong, bisakah senam } \\
\text { di balkon,” kataku tegas. } \\
\text { "Kalau terus senam di situ } \\
\text { aku jadi terbangun.” } \\
\text { B: “Tapi ini sudah jam } \\
\text { setengah tujuh!” katanya } \\
\text { dengan mimik tidak } \\
\text { percaya. (p. 22) }\end{array}$ & $\begin{array}{l}\text { Even though speaker A's complaint } \\
\text { was not responded with an apology, } \\
\text { but instead showed what time it } \\
\text { was, it was a defense from Speaker } \\
\text { B that he was exercising at the right } \\
\text { time, because it was normal for } \\
\text { people to wake up. }\end{array}$ \\
\hline 12 & $\begin{array}{l}\text { A: "We're almost } \\
\text { there," said } \\
\text { Reiko. "This is } \\
\text { about two-thirds } \\
\text { of the way. Come } \\
\text { on, you're a boy, } \\
\text { aren't you?" } \\
\text { B: "Yeah, but } \\
\text { I'm out of } \\
\text { shape." (p.165) }\end{array}$ & $\begin{array}{l}\text { A: "Kita sudah melewati } \\
\text { dua pertiganya, tinggal } \\
\text { sedikit lagi. Kamu laki-laki, } \\
\text { kan? Harus kuat," kata } \\
\text { Reiko-san. } \\
\text { B: “Aku kurang } \\
\text { olahraga." (p.203) }\end{array}$ & $\begin{array}{l}\text { Even though Speaker B does not } \\
\text { defend himself that gender is not a } \\
\text { reference to strong mountaineering, } \\
\text { his answer to rarely exercising is } \\
\text { the main reason why he loses in } \\
\text { performance to Speaker A. }\end{array}$ \\
\hline 13 & $\begin{array}{l}\text { A: "Are you hard } \\
\text { now?" }\end{array}$ & $\begin{array}{l}\text { A: “Sekarang tegang?” } \\
\text { B: “Telapak kakiku?" } \\
\text { (p.211) }\end{array}$ & $\begin{array}{l}\text { Although Speaker A's questions } \\
\text { were answered by Speaker B's } \\
\text { questions, Speaker A was able to }\end{array}$ \\
\hline
\end{tabular}




\section{B: "You mean}

the soles of $\mathrm{my}$

feet?" (p.171) grasp the point, because at that time they were making love.

14 A: "Hey, you're

A: "Lihai juga ya?" kataku.

Instead of saying thank you,

pretty good at

B: “Anak manis harus

Speaker B told to Speaker A to be

that," I said.

diam," kata Naoko. (p.212) quiet, because Speaker A's praise

B: "Be a good had a sexual tendency.

boy and shut

up," said Naoko.

(p.172)

15 A: "I'd like to hang around here a few days if I can. Can you put me up? I won't get in your way."

B: "No problem," I said.

"I have a big

closet I can sleep

in, in my

sleeping bag."

(p.332-333)

\section{A: "Ya. Kalau bisa aku}

ingin bersantai dulu dua-tiga hari. Boleh aku tinggal di rumahmu? Aku tidak akan menyusahkanmu.

B: "Ya, sangat boleh. Aku akan tidur di kantong

tidur." (p.404)
Instead of convincing Speaker A that she won't be troublesome, Speaker B delivered an implied message that he invited Speaker A to sleep on the mattress, while he slept in his sleeping bag.

\section{$\underline{\text { Manner }}$}

\begin{tabular}{llll}
\hline No & \multicolumn{1}{c}{ BSu } & \multicolumn{1}{c}{ BSa } & \multicolumn{1}{c}{ Analysis } \\
\hline 16 & A: “Then what & A: "Setelah menelannya & Speaker A got information from \\
happened?" & bagaimana?" & Speaker B orderly about what \\
B: "I went back & B: "Aku segera kembali ke & Speaker A did after eating three \\
to my room and & kamar dan minum air & leeches alive. \\
drank a bucket & garam sebanyak- & \\
of salt water. & banyaknya," kata & \\
\hline
\end{tabular}




\section{What else could Nagasawa-san. "Karena}

I do?" (p.40) tak ad acara lain lagi."

17 A: "What time are A: "Besok kamu pulang jam Speaker B explained specifically you leaving berapa?" tanya Reiko-san when he would return. In addition, tomorrow?" menghentikan latihannya giving reasons regarding the

Reiko asked me, dan menyalakan rokok. schedule.

taking abreak and

B: "Setelah sarapan. Jam

lighting a sembilan bisa kan datang,

cigarette. jadi aku tidak usah bolos

B: "Straight bekerja paruh waktu."

after breakfast," (p.220)

I said. "The bus

comes at nine.

That way I can

get back in time

for tomorrow night's work." (p.178)

18 A: "Yeah, I'm free. Where are you?"

\section{B: "Ueno}

Station. Why

don't you meet

me in Shinjuku?

I'll leave now."
A: "Aku senggang. Kamu sekarang di mana?"

B: "Stasiun Ueno. Aku akan ke Shinjuku sekarang, mau ketemu?" (p.324)

(p.263)

19 A: "Where do you A: "Mau ke mana want to go now?" sekarang?" tanyaku. I asked. B: "Kita datang ke

B: "The roof, of course. That's department store, makan di would do there.

$$
\text { kafetarianya, selanjutnya }
$$

Speaker B not only informs where he was at the moment, but captures the intent of Speaker A who wants to meet. 


\author{
the next stop sudah pasti ke balkon \\ when you've had gedung ini.” (p.379) \\ lunch in a \\ department- \\ store \\ restaurant."
}

(p.312)

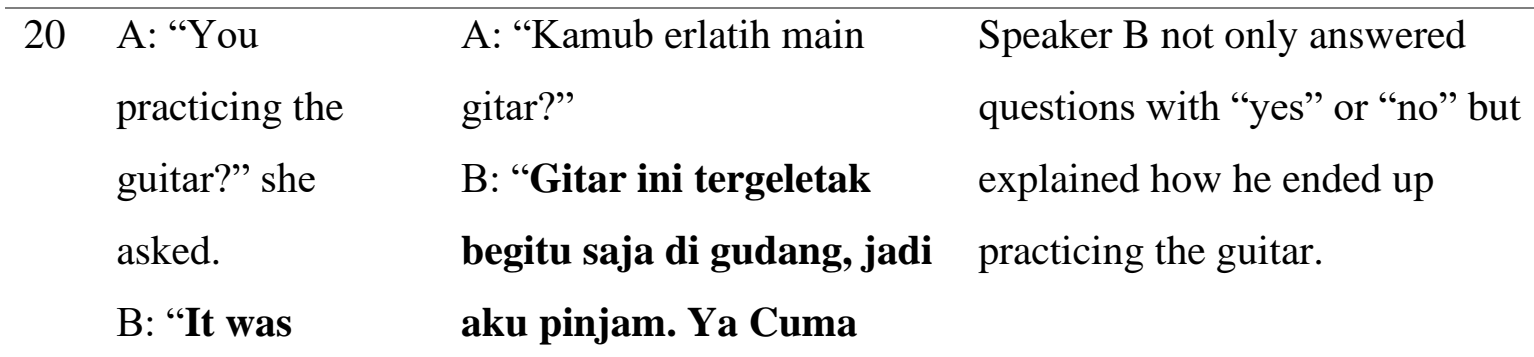

kicking around

petik-petik saja.” (p.407)

the landlord's

storehouse, so I

borrowed it and

I plunk on it

once in a while.

That's all."

(p.335)

From table 1 it can be seen that the 20 data retrieved were grouped into the existing types of maxim. The utterance also presented the thoughts of the characters in the novel. The value of "coming of age" can also be seen from the way they are in a dark situation such as drunkenness or showing a tendency to be sloppy.

\title{
Use of Translation Techniques
}

After reviewing English version of the Norwegian Wood novel, the translation technique was found as follows: Established Equivalent, Amplification: Explicitation and Paraphrase, Reduction, Variation, Creation Discursive, Modulation, Paraphrase, Pure 
Borrowing, Generalization, Linguistic Compression: Implicitation. Through the calculating process, the percentage was obtained as presented in the table below.

Table 2. Percentage of translation techniques based on the amount of data taken

\begin{tabular}{lllll}
\hline No & Translation Technique & Frequency & Percentage \\
\hline 1 & Established Equivalent & 23 & $37,09 \%$ \\
\hline \multirow{2}{*}{2} & Amplification & Explicitation & 10 & $16,12 \%$ \\
\cline { 3 - 4 } & & Paraphrase & 3 & $4,83 \%$ \\
\hline 3 & Reduction & 7 & $11,29 \%$ \\
\hline 4 & Variation & 6 & $9,67 \%$ \\
\hline 5 & Creation Discursive & 5 & $8,06 \%$ \\
\hline 6 & Modulation & 3 & $4,83 \%$ \\
\hline 7 & Pure Borrowing & 2 & $3,22 \%$ \\
\hline 8 & Generalization & 2 & $3,22 \%$ \\
\hline 9 & Linguistic Compression & Implicitation & $1,61 \%$ \\
\hline Total & & 62 & $100 \%$ \\
\hline & & & \\
\hline
\end{tabular}

One way to judge a translation product is to involve rater in giving an assessment. This method was initiated by Nababan et al (2012), commonly called as quality level which includes accuracy, acceptance, and readability. As for the rating given ranging from 1 to 3 . Based on this research, the following results were obtained:

Table 3. The level of translation assessment

\begin{tabular}{|c|c|c|c|}
\hline No & Accuracy Level & Data & Percentage \\
\hline 1 & Accurate & 16 & $80 \%$ \\
\hline 2 & Less Accurate & 2 & $10 \%$ \\
\hline
\end{tabular}




\begin{tabular}{|c|c|c|c|}
\hline 3 & Not Accurate & 2 & $10 \%$ \\
\hline No & Acceptability Level & Data & Percentage \\
\hline 1 & Acceptable & 20 & $100 \%$ \\
\hline 2 & Less Acceptable & - & $0 \%$ \\
\hline 3 & Not Acceptable & - & $0 \%$ \\
\hline No & Readability Level & Data & Percentage \\
\hline 1 & Readable & 20 & $100 \%$ \\
\hline 2 & Less Readable & - & $0 \%$ \\
\hline 3 & Not Readable & - & $0 \%$ \\
\hline
\end{tabular}

The level of translation assessment in each aspect was influenced by the translation technique used. On accuracy aspect, there are 2 less accurate data and 2 inaccurate data. This is due to the use of Creation Discursive technique as presented in data number 2 and 3. Data number 2 produces a score of 2 because it has changed the tendency from a character's words that seem mocking to be seductive especially with the addition of "dong" through the application of Variation translation technique. Meanwhile, the accuracy score in data number 3 is 1 because the application of Creation Discursive translation technique makes translator add an improvisation that is completely different to source language text. Nevertheless, the score of acceptability and readability is maintained, namely 3 . This is due to the fact that the impact of a translation technique does not always occur in all aspects. Moreover, the application of Creations Discursive to fiction work is understandable because it can increase its attractiveness. Combined with Variation translation techniques, the value of "coming of age" can also be presented well. On the other hand, the Reduction translation technique on the data presented does not affect the assessment because the things that are reduced are only additional, not something important that can affect the essence of the story. The apt use of this translation technique will actually make a delivery more effective. 
The use of Creation Discursive translation technique that lessen the score of accuracy aspect is also found in study by Rahmawati et al (2016) and Ekowati et al (2017). Rahmawati studies about sexism expressions and Creation Discursive translation technique make those expressions lead to semantic derogation. The consideration of translator in using that translation technique is to dramatize the sexism expressions (considering the novel being studied is in the adult category) in target language, but the consequence it lessens the accuracy aspect. In other word, the translator changes the author's intent to sexism expressions. Meanwhile, Ekowati studies about metaphor that is found in the novel by Khaled Hosseini. The use of Creation Discursive translation makes an expression lost the metaphor. In this case, the translator does not understand about the metaphor. As a result, there is a loss with author's intent as well as story feel.

In this study, Reduction translation technique does not lessen the assessment in any aspect. This finding is line with study by Afwah (2019). The implementation of that translation technique is used to reduce the taboo substance regarding subtitle in American Pie series. In other word, Reduction translation technique is not always inclement if used in the right context.

\section{CONCLUSION}

To sum up, the translator uses nine types of translation techniques on the 20 data in which Established Equivalent and Amplification: Explicitation and Paraphrase are the most commonly used. On the other hand, Creation Discursive gives the impact on accuracy aspect. The value of "coming of age" contained in the novel or object of research is presented in all types of maxim which represents the thoughts of the character toward maturity. Regarding to translation aspect, a combination of Creation Discursive and Variation can show that value through social tone in target text. In addition, there is no inclement translation technique as long as it is used in the right context.

\section{REFERENCES}

Afwah, A. (2019). Analisis delesi dan reduksi dalam subtitle film American Pie 1-7. Unpublished thesis, Universitas Sebelas Maret. 
Christy, G. M. A. (2016). Bildungsroman. The Dawn Journal, 5 (1), 1234-1237.

Cutting, J. (2002). Pragmatics and discourse: A resource book for students. Routledge.

Dänzer, L. (2017). Utterance understanding, knowledge, and belief. Ergo, 4 (18). https://doi.org/10.3998/ergo.12405314.0004.018

Ekowati, E., Nababan, M.R., \& Santosa, R. (2017). Analisis teknik dan kualitas terjemahan ungkapan bermajas metafora pada novel "A Thousand Splendid Suns" karya Khaled Hosseini. Prasasti Journal of Lingusitics, 2 (2), 222-236. https://doi.org/10.20961/prasasti.v2i2.2078

Moleong, L.J. (2005). Metodologi Penelitian Kualitatif. Remaja Rosdakarya.

Permatasari, S.N., Yulia, M.F. (2016). An analysis on the language style of the utterances in Magnum Advertisements. LLT JOURNAL, $16 \quad$ (1), 1410-7201. https://doi.org/10.24071/1lt.v16i1.280.g239

Rahmawati, A.A. M.R. Nababan. Santosa, R. (2016). Kajian teknik penerjemahan dan kualitas terjemahan ungkapan yang mengandung Seksisme dalam novel The Mistress's Revenge dan novel The 19th Wife. Prasasti, 1 (2), 249-270. https://doi.org/10.20961/prasasti.v1i2.1032

Sua, A.T. Anshari, A. Maman, M. (2017). The form, function, and value of Buginese Utterances of Bone Society. Journal of Language Teaching and Research, 8 (5), 928933. http://dx.doi.org/10.17507/jltr.0805.12

Sutopo. (2006). Metodologi Penelitian Kualitatif. Universitas Sebelas Maret.

Whiteboard Journal (2018, November 15). Minimnya genre coming of age dalam sastra Indonesia. https://www.whiteboardjournal.com/column/minimnya-genre-coming-ofage-dalam-sastra-indonesia/ 